\title{
Effects of short period frequent milking on milk yield in two East Friesian crosses: Tahirova and Sonmez sheep
}

\author{
Akin Pala and Sefer Sahin \\ Canakkale Onsekiz Mart University, Department of Animal Science, Canakkale, Turkey
}

\begin{abstract}
Though East Friesian sheep are known to have very high milk yield, their various degree crosses may have different levels of milk yield under different conditions due to genotype $x$ environment interaction. The major purpose of this study was to investigate whether increasing milking frequency for a short period (21 days) increases milk yield in two East Friesian crosses, Tahirova and Sonmez sheep. Tahirova is $75 \%$ East Friesian and $25 \%$ Kivircik, while Sonmez is $75 \%$ Tahirova and $25 \%$ Sakiz (Chios). Two milking groups were formed and were treated the same in terms of feeding and management. The sheep in the $4 \times$ group were milked 4 times a day after weaning for a short period, namely 21 days and then were milked twice a day for the rest of the lactation. The sheep in the $2 \times$ group were milked twice a day throughout the whole milking season. Repeated measures analyses indicated that overall differences between the $2 \times(520.68 \mathrm{~g})$ and $4 \times(873.03 \mathrm{~g})$ groups were highly significant for milk yield $(P<0.01)$. Parity differences were significant in the treatment group and the 3rd lactation animals responded better to the $4 \times$ treatment $(P<0.01)$, but they were non-significantly different than the 2 nd lactation animals in the $2 \times$ group. Sheep in the $4 \times$ group had higher milk fat yield $(P=0.02)$ but the groups were similar in terms of fat percentage $(P=0.11)$. Differences between the breeds were highly significant $(P<0.01)$ also. Tahirova breed, which has a higher percentage of East Friesian had a daily milk yield of $566.66 \mathrm{~g}$, while Sonmez breed with a lower percentage of East Friesian produced a higher daily milk yield of $827.05 \mathrm{~g}$. Results of this study suggests that increasing milking frequency for a short time increases milk yield throughout lactation, especially for older animals, and sheep with too high East Friesian breeding may have lower milk yield than those with lower East Friesian breeding.
\end{abstract}

Keywords: East Friesian sheep, Tahirova, Sonmez, milk yield, frequent milking

\section{Zusammenfassung}

\section{Auswirkungen von kurzzeitigem, häufigem Melken auf die Milchleistung von zwei Ostfriesischen Milchschafkreuzungen: Tahirova und Sonmez Schafe}

Obwohl Ostfriesische Milchschafe für sehr hohe Milchleistungen bekannt sind, können die verschiedenn Kreuzungen unter verschiedenen Genotyp $\times$ Umweltbedingungen unterschiedliche Milchleistungen haben. Untersucht wurde, ob die Melkfrequenz für einen kurzen Zeitraum (21 Tage) die Milchleistung bei den beiden Kreuzungen Tahirova (75\% Ostfriesisches Milchschaf und 25\% Kivircik und Sonmez Schaf (75\% Tahirova und 25\% Sakiz [Chios] beeinflusst. Dazu wurden zwei Gruppen gebildet für die die gleichen Futter- und 
Haltungsbedingungen galten. Die Schafe in der der 4x-Gruppe wurden nach dem Absetzen 21 Tage lang viermal täglich und für den Rest der Laktation zweimal täglich gemolken. Der Schafe der $2 \times$-Gruppe wurden zweimal täglich während der gesamten Laktation gemolken. Wiederholte Analysen der Messwerte ergaben, dass die Unterschiede in der Milchleistung für die $2 x-(520,68)$ und die $4 x$-Gruppe $(873,03 \mathrm{~g})$ hochsignifikant waren $(P<0,01)$. Bei den Schafen der $4 \times$-Gruppe war die Milchfettausbeute zwar höher $(P=0,02)$, aber die Gruppen ähnelten sich in Bezug auf den Fettgehalt $(P=0,11)$. Die Tahirova Schafe mit dem höheren Kreuzungsanteil vom Ostfriesischen Milchschaf gaben täglich 556,66 g Milch, Sonmez Schafe mit einem geringeren Kreuzungsanteil täglich 827,05 g Milch. Die Ergebnisse der Studie legen nahe, dass eine Erhöhung der Melkfrequenz für kurze Zeit auch die Milchleistung während der Laktation erhöht. Dies gilt vor allem für ältere Tiere. Schafe mit einem zu hohen Kreuzungsanteil vom Ostfriesischen Milchschaf können eine geringere Milchleistung aufweisen als solche mit einem niedrigeren Anteil.

Schlüsselwörter: Ostfriesisches Milchschaf, Tahirova, Sonmez, Milchleistung, häufiges Melken

\section{Introduction}

Increasing milking frequency for a short period during lactation has been attempted in dairy cattle (Bar-Peled et al. 1995, Dahl et al. 2004) and in dairy goats (Pala \& Koyuncu 2007, Koyuncu \& Pala 2008) with success, increasing milk yield with no significant change in somatic cell count (SCC). However, there are no records of increasing milking frequency for a short period in sheep. Many studies in sheep either used half-udder experiments or investigated whether milking the animals once-a-day instead of the usual twice-a-day decreased milk yield (Gursoy et al. 2001, Stelwagen 2001, Nudda et al. 2002). In an enterprise, if the sheep flock is kept mainly for dairy purposes, and the flock is composed of dairy breeds such as East Friesian or Awassi crosses, then increasing milk yield should be the main aim for the producer. Purroy (1986) and Capuco et al. (2003) reported that increasing milking frequency in sheep increases milk yield. However, increasing milking frequency may also increase labor costs and this is a major obstacle in milking frequency decisions. It was reported in dairy cattle (Dahl et al. 2004) and in dairy goats (Koyuncu \& Pala 2008) that increasing milking frequency for a short period keeps the increased milk yield long after the treatment is ceased. The change may be due to various reasons such as changing cell number or activity, feedback inhibition, and apoptosis (Stelwagen 2001). The short period increase in milking frequency may help keep labor costs down and milk yield up and thus increase profits if the feeding plane is kept the same despite the increased milk frequency and thus increased milk yield. If both groups were fed the same ration this helps illustrate whether increasing milking frequency in sheep increases milk yield without additional feed. The animals in the $4 \times$ group may benefit more from pasture to support the higher milk yield (Koyuncu \& Pala 2008).

Various degree crosses may have different success rates. Thomas et al. (2000) reported that many countries imported East Friesian sheep yet in many instances, success rate was low for survival, lamb production, and even milk production compared to local breeds, especially when more than $50 \%$ East Friesian breeding existed in the crossbreds. Tahirova and Sonmez 
sheep are expected to have high milk yield due to East Friesian breeding but too high East Friesian breeding may reverse the benefits.

The major purpose of this study was to investigate the effects of a three weeks period of frequent (4 times a day) milking on milk yield in two crosses with different East Friesian breeding, Tahirova and Sonmez sheep.

\section{Materials and methods}

This study was carried out in the premises of Altayreaktif Ltd. Company, Turkey. The study included ewes with two breeds, Tahirova $(n=15)$ and Sonmez $(n=18)$, two milking schemes $(2 \times, n=17 ; 4 \times, n=16)$ and $2 n d(n=17)$ and 3rd $(n=16)$ lactation. Tahirova sheep (Demiroren 2002) are $75 \%$ East Friesian and $25 \%$ Kivircik (Akçapinar et al. 2000). Sonmez sheep are $75 \%$ Tahirova and $25 \%$ Sakiz (Chios). Sheep in the $2 \times$ group were milked twice a day throughout lactation. Sheep in the $4 \times$ group were milked 4 times a day for 3 weeks and then were milked twice a day for the rest of the lactation. The lambs were kept with their dams and the experiment started after the lambs were weaned. The $2 \times$ group sheep were milked at 09.00 and $18.00 \mathrm{~h}$. The $4 \times$ group sheep were milked at $07.00,12.00,18.00$ and 23.00 for 21 days, and then were milked the same as the $2 \times$ group.

The animals were put on an artificial pasture composed of fodder oat, alfalfa and three different commercial pasture mixes. They were also supplemented with a $500 \mathrm{~g}$ ration of wheat, barley, rye, oats, corn, alfalfa and sunflower meal per head basis. Both groups were fed the same ration. All animals were milked manually and the harvested milk was weighed using a digital scale. Milk fat, milk protein, non-fat milk solids and lactose levels of raw sheep milks were measured using the Milk Analyzer (Lactoscan 90, Bulgaria) and SCC was measured using Fossomatic (Miller et al. 1986). Milk components and SCC was measured during the test days.

The covariance structure tests and the analyses were similar to those reported by Pala \& Koyuncu (2007). Proc MIXED of SAS V8.2 (SAS 1999) was used with the repeated statement to fit a lactation curve model and the first order Unstructured variance-covariance model (Pala \& Koyuncu 2007). Akaike information criterion (Akaike 1974) and Schwarz Bayesian criterion (Schwarz 1978) were computed (SAS 1999) and both of these fitness measures indicated that the first order Unstructured method had the highest fit along with four other structures, namely First-order Ante Dependence, Huynh-Feldt, First-order Heterogeneous Toeplitz and Variance Components. For somatic cell score (SCS) repeated analyses, the Toeplitz structure had a high fitness (low AIC and BIC scores) as well. The Unstructured variance-covariance structure was used in the analyses. The model included breed (Tahirova and Sonmez), group ( $2 \times$ and $4 \times$ ), parity ( 2 and 3), test day (1, 2, 3, 4 and 5), two way interactions of these factors and days in milk (DIM) within parity. Various transformations of DIM were included as described by Pala \& Koyuncu (2007). Individual sheep were included as subject within parity. The traits investigated were peak milk yield, DIM at peak, test day milk yield, fat corrected milk yield, SCC transformed value SCS, milk fat (kilograms and percentage), percent milk protein, percent non-fat milk solids and percent lactose. Somatic Cell Score was calculated as described by Koyuncu \& Pala (2008) by log transforming the SCC to SCS using the equation:

$$
S C S=\log 2(S C C / 100)+3
$$




\section{Results and discussion}

Sheep in the $4 \times$ group had higher peak milk yield compared to those in the $2 \times$ group. This can also be seen in Figure 1 clearly, indicating that milking sheep more frequently after weaning increased peak milk yield significantly. This is in contrast to a goat study by Koyuncu \& Pala (2008), who reported that $2 \times$ and $4 \times$ goats had similar peak milk yield. However, more frequently milked animals having higher milk yield agrees with Dahl et al. (2004), who reported that cows milked 6 times a day had higher milk yield compared to those milked 3 times a day.

Overall, sheep in the $4 \times$ group had $352.35 \mathrm{~g}$ higher milk yield compared to those in the $2 \times$ group ( 873.03 vs. $520.68 \mathrm{~g})$ and the differences were highly significant $(P<0.001)$. This indicates that milking sheep 4 times a day for 3 weeks increases milk yield around $68 \%$ compared to milking them twice a day throughout lactation. This increase is a lot higher than the increases reported in literature. Koyuncu \& Pala (2008) milked Saanen goats 4 times a day for 21 days and reported an overall $12 \%$ increase in milk yield. Knight (1992) reported $10.4 \%$ increase in milk yield during 6 weeks of thrice a day milking of goats. Nudda et al. (2002) milked three sheep breeds once or twice a day and reported that decreasing milking frequency decreased milk yield by $24 \%$ in Sarda, by $18 \%$ in Awassi and by $23 \%$ in Merino breeds. The authors concluded that there was no difference between the dairy breeds (Sarda and Awassi) and the Merino in terms of being affected by milking frequency.

Differences between the $2 \times$ and the $4 \times$ sheep were large enough to be highly significant for fat corrected milk yield as well (Table 1). The differences for fat corrected milk yield had the same trends as those for the milk yield.

Table 1

Repeated measures analyses, including least squares means comparisons of production traits of sheep milked 2 times/d $(2 \times)$ or 4 times/d $(4 x)$ for the $21 \mathrm{~d}$ of lactation after weaning

\begin{tabular}{lrrrr}
\hline Trait & $2 \times$ & $4 \times$ & \multicolumn{1}{c}{ SEM $^{1}$} & \multicolumn{1}{c}{$P$} \\
\hline Peak milk, g & 763.50 & 1213.13 & 103.08 & $<0.01$ \\
Test day milk, g & 520.68 & 873.03 & 48.47 & $<0.01$ \\
Fat corrected test day milk, g & 732.54 & 986.89 & 79.46 & $<0.01$ \\
Somatic Cell Score & 13.78 & 14.12 & 0.25 & 0.33 \\
Milk fat, kg & 35.68 & 45.27 & 3.08 & 0.02 \\
Milk fat, $\%$ & 7.20 & 6.49 & 0.33 & 0.11 \\
Milk protein, \% & 5.92 & 5.89 & 0.06 & 0.72 \\
Non-fat solids, $\%$ & 10.79 & 10.92 & 0.11 & 0.36 \\
Lactose, \% & 3.89 & 3.97 & 0.05 & 0.31 \\
\hline
\end{tabular}

'Pooled standard error of the mean based on most conservative number in a group.

There were no sheep with clinical mastitis and the herd was in a good shape overall in terms of udder health. Koyuncu \& Pala (2008) reported that $P$-values of the $\chi 2$, continuity adjusted $\chi^{2}$ and repeated analyses of SCS did not make a difference in terms of significance. In this study, repeated analysis of SCS indicated that differences between the $2 \times$ and $4 \times$ groups were non-significant and these differences were non-significant in all test days, which was expected because group by test day was non-significant. The other analyses agreed with these results, as SCC $\chi^{2}$ indicated non-significant differences. 


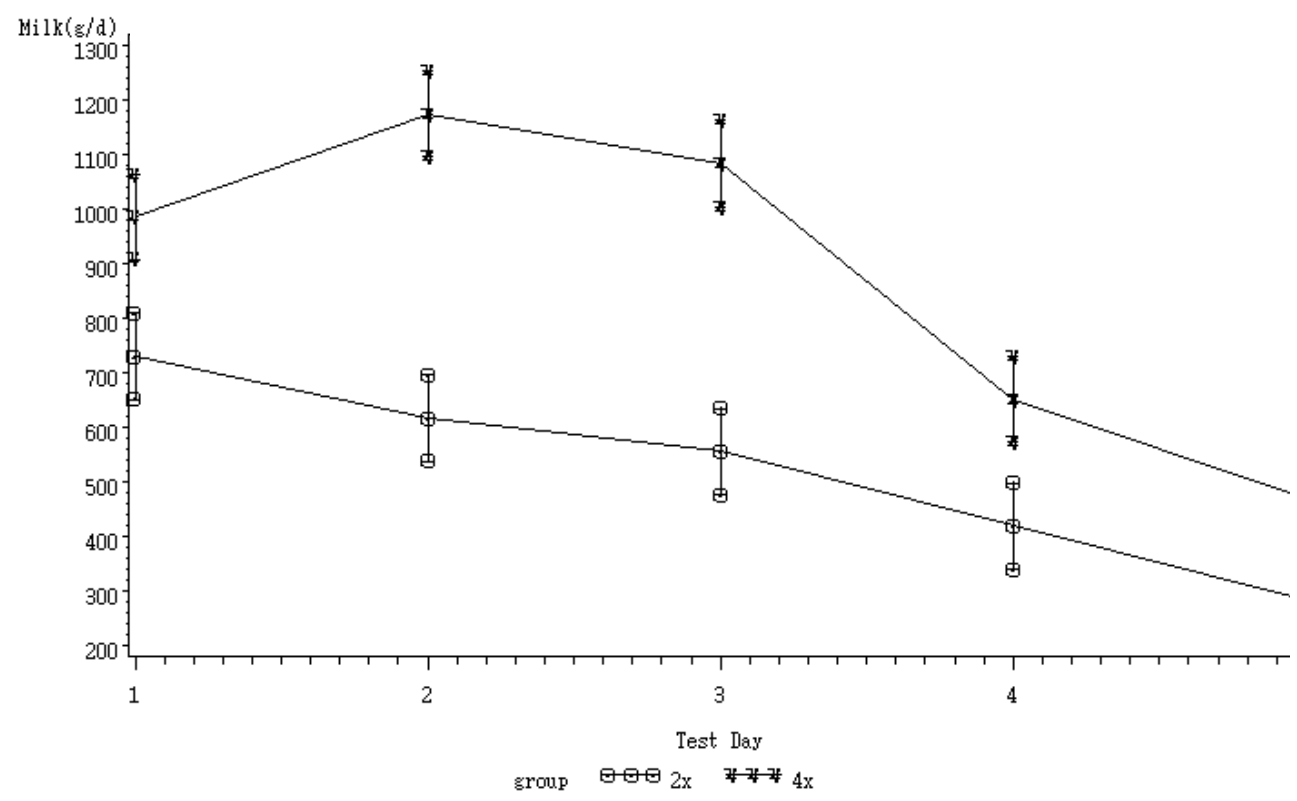

Figure 1

Test day average (least squares mean) milk yield of sheep milked 4 times/d (4x) for $21 \mathrm{~d}$ after weaning or milked 2 times/d $(2 \times)$ for $21 \mathrm{~d}$ after weaning of lambs. All sheep were milked $2 \times$ for the rest of the lactation. Differences were large from first to fourth test days $(P<0.05)$, but were smaller in the fifth test day $(P=0.093)$.

Sheep in the $4 \times$ group had significantly higher milkfat yield compared to the $2 \times$ group (Table 1 , $P=0.02)$. However, the 4 group had slightly lower milk fat percentage compared to the $2 \times$ group $(P=0.11)$ and the differences between the groups were non-significant. These results indicate that though frequent milking increased milk yield and milk fat yield, milk fat yield did not increase as fast as the milk yield increased, which resulted in non-significant milk fat percentage differences between the milking groups. Milk protein, non-fat solids and lactose differences were non-significant (Table 1). Koyuncu \& Pala (2008) reported that the goats in their $2 \times$ group had significantly higher fat percentage than the $4 \times$ group, but differences between the groups for protein and non-fat solids were non-significant. Similar results were reported by McKusick et al. (2002) in sheep, by Salama et al. (2003) in goats, and by LacyHulbert et al. (1999) in dairy cattle. Salama et al. (2003) speculated that differences for fat percentage could be because of increased fat concentration in the low milk yield group and the other differences could be because of differences in milk component synthesis in different groups. Cimen \& Karaalp (2009) used 16 ewes with their lambs to compare restricted suckling time (R) and free suckling time (F) methods, and reported that there were no significant differences between treatments in terms of milk protein, while milk fat concentrations were higher in the F group than in R group until the 4th week of their study.

Differences between Tahirova and Sonmez breeds for peak milk yield were non-significant, though Tahirova breed had a higher peak milk yield (Table 2). However, differences between the breeds were highly significant $(P<0.001)$ for test day milk yield. Sonmez had $260.39 \mathrm{~g}$ higher daily milk yield compared to the Tahirova breed (Table 2). Sonmez has approximately $56 \%$ 
East Friesian breeding and Tahirova has a higher, $75 \%$ East Friesian breeding. Tahirova having a lower milk yield compared to Sonmez agrees with Thomas et al. (2000), who reported that East Friesian breeding higher than $50 \%$ may be detrimental in various traits, including milk yield. The reason for this could be because resistance to local parasites and various diseases may be higher in the local Turkish breeds included in crossbreeding these sheep. Too high East Friesian breeding may have caused Tahirova to have problems and Sonmez may have an advantage due to Sakiz (Chios), which is a local breed known to have good resistance to parasites. Tahirova breed having a higher peak could simply be attributed to chance, as the differences were non-significant for that trait. There are literature reports that tie higher milk yield to higher persistency (Pala \& Koyuncu 2007), which could be the case here, as Tahirova sheep had lower milk yield and higher peak yield, indicating a low persistency. Sonmez breed had higher milk yield with a low peak, indicating a higher persistency.

Table 2

Repeated measures analyses, including least squares means comparisons of production traits of different breeds of sheep, Tahirova and Sonmez

\begin{tabular}{|c|c|c|c|c|}
\hline Trait & Tahirova & Sonmez & SEM $^{1}$ & $P$ \\
\hline Peak milk, g & 1078.50 & 898.13 & 106.69 & 0.22 \\
\hline Test day milk, g & 566.66 & 827.05 & 51.21 & $<0.01$ \\
\hline Fat corrected test day milk, g & 771.46 & 947.98 & 67.57 & 0.04 \\
\hline Somatic Cell Score & 13.58 & 14.32 & 0.25 & 0.03 \\
\hline Milk fat, kg & 37.36 & 43.59 & 3.26 & 0.13 \\
\hline Milk fat, \% & 7.09 & 6.60 & 0.35 & 0.27 \\
\hline Milk protein, $\%$ & 5.93 & 5.88 & 0.06 & 0.54 \\
\hline Non-fat solids, $\%$ & 10.84 & 10.87 & 0.12 & 0.84 \\
\hline Lactose, $\%$ & 3.92 & 3.94 & 0.06 & 0.78 \\
\hline
\end{tabular}

'Pooled standard error of the mean based on most conservative number in a group.

Effects of breed was significant for SCS $(P=0.03)$, indicating the breeds had different levels of udder health. Sonmez sheep had a higher level of SCS compared to the Tahirova breed. This is expected because Sonmez sheep had higher milk yields and higher milk yield provides more feeding ground for bacteria in udders, increasing SCC and thus, SCS. Olechnowicz et al. (2010) worked with dairy sheep and reported that estimates of SCC in milk samples from udders are related to the records obtained from either one half of the udder.

Sonmez breed had higher milk fat yield compared to the Tahirova breed, but the differences were non-significant. The $P$-value was higher for percentage fat in milk compared to milk fat yield (Table 2), and percentage of milk fat in the Sonmez breed was lower than that of Tahirova. This is the same trend as in the group (Table 1), because the group with the higher milk yield had significantly higher milk fat yield but non-significantly lower percentage of fat in milk. Both measures were non-significant for the breeds.

Effects of breed on milk protein, non-fat solids and lactose were non-significant; indicating the differences between the breeds can be attributed to chance for these milk components. The $P$-values for these traits ranged from 0.54 to 0.84 , which are quite high.

Group by breed interaction was non significant for milk yield $(P=0.30)$, fat corrected milk yield $(P=0.65)$, percent fat $(P=0.73)$, percent protein $(P=0.09)$, percent non-fat solids $(P=0.18)$, percent lactose $(P=0.21)$, milk fat yield $(P=0.65)$, peak milk yield $(P=0.62)$ and for SCS $(P=0.65)$. 
This indicates that differences between the breeds did not change in different groups and the Sonmez breed had higher milk yield regardless of the milking frequency and milking frequency did not change the rank of the breeds significantly for the other traits. Breed by parity, breed by test day and parity by test day interactions were non significant $(P>0.05)$ as well.

Breed by milking frequency group interaction was provided in Table 3. Both test day milk yield and SCC followed the same trend as in the main effects. Differences between the $2 x$ and $4 \times$ groups test day milk yields were highly significant for both breeds. SCC differences were non-significant in both breeds, that is differences seen between the $2 \times$ and $4 \times$ groups for SCS can be attributed to chance. All other trait differences showed an interesting pattern, they were largely significant for Sonmez breed, which had less East Frieasian breeding, but had higher milk yield, compared to the Tahirova breed. Combined with the parity results, where 3rd lactation animals with higher milk yield had better success with the $4 \times$ treatment (Table 4), this is a strong indication that animals with higher milk yields respond better to an increase in milking frequency.

Table 3

Repeated measures analyses, including least squares means of production traits of breed by milking frequency interaction

\begin{tabular}{|c|c|c|c|c|c|c|c|}
\hline \multirow[t]{2}{*}{ Trait } & \multicolumn{2}{|c|}{ Tahirova } & \multirow[t]{2}{*}{$P$} & \multicolumn{2}{|c|}{ Sonmez } & \multirow[t]{2}{*}{$P$} & \multirow[t]{2}{*}{$\mathrm{SEM}^{1}$} \\
\hline & $2 x$ & $4 \times$ & & $2 x$ & $4 \times$ & & \\
\hline Peak milk, g & 710.0 & 1086.25 & 0.09 & 817.0 & 1340.0 & 0.01 & 155.8 \\
\hline Test day milk, g & 417.61 & 715.70 & $<0.01$ & 623.74 & 1030.36 & $<0.01$ & 67.9 \\
\hline Fat corrected test day milk, g & 659.92 & 883.00 & 0.04 & 805.16 & 1090.79 & 0.01 & 89.5 \\
\hline Somatic Cell Score & 13.33 & 13.83 & 0.33 & 14.22 & 14.41 & 0.70 & 0.4 \\
\hline Milk fat, kg & 33.33 & 41.39 & 0.12 & 38.03 & 49.15 & 0.04 & 4.32 \\
\hline Milk fat, $\%$ & 7.51 & 6.67 & 0.14 & 6.89 & 6.30 & 0.31 & 0.47 \\
\hline Milk protein, $\%$ & 5.99 & 5.86 & 0.17 & 5.84 & 5.92 & 0.43 & 0.08 \\
\hline Non-fat solids, $\%$ & 10.86 & 10.83 & 0.88 & 10.73 & 11.02 & 0.12 & 0.15 \\
\hline Lactose, \% & 3.92 & 3.92 & 0.98 & 3.86 & 4.01 & 0.12 & 0.08 \\
\hline
\end{tabular}

Pooled standard error of the mean based on most conservative number in a row.

Table 4

Repeated measures analyses, including least squares means of production traits of parity by milking frequency interaction

\begin{tabular}{|c|c|c|c|c|c|c|c|}
\hline \multirow[t]{2}{*}{ Trait } & \multicolumn{2}{|c|}{ 2nd Lactation } & \multirow[t]{2}{*}{$P$} & \multicolumn{2}{|c|}{ 3rd Lactation } & \multirow[t]{2}{*}{$P$} & \multirow[t]{2}{*}{ SEM $^{1}$} \\
\hline & $2 \times$ & $4 \times$ & & $2 \times$ & $4 \times$ & & \\
\hline Peak milk, g & 656.77 & 1105.0 & 0.035 & 880.62 & 1321.25 & 0.045 & 149.85 \\
\hline Test day milk, g & 496.85 & 705.85 & 0.03 & 544.51 & 1040.22 & $<0.01$ & 79.90 \\
\hline Fat corrected test day milk, g & 779.28 & 842.06 & 0.61 & 685.80 & 1131.72 & $<0.01$ & 105.07 \\
\hline Somatic Cell Score & 13.73 & 13.98 & 0.58 & 13.83 & 14.25 & 0.40 & 0.36 \\
\hline Milk fat, kg & 39.44 & 39.42 & 0.99 & 31.93 & 51.12 & $<0.01$ & 5.07 \\
\hline Milk fat, $\%$ & 7.76 & 6.73 & 0.11 & 6.64 & 6.25 & 0.53 & 0.55 \\
\hline Milk protein, $\%$ & 5.99 & 5.98 & 0.91 & 5.85 & 5.81 & 0.69 & 0.09 \\
\hline Non-fat solids, $\%$ & 10.81 & 11.04 & 0.28 & 10.77 & 10.81 & 0.84 & 0.18 \\
\hline Lactose, $\%$ & 3.87 & 4.01 & 0.19 & 3.91 & 3.92 & 0.94 & 0.09 \\
\hline
\end{tabular}

Pooled standard error of the mean based on most conservative number in a row. 
Effects of parity on milk yield were non significant $(P>0.05)$ but group by parity interaction was significant $(P=0.03)$. Sheep in the $4 \times$ group and in their 3rd lactation had the highest milk yield ( $1040.22 \mathrm{~g})$, followed by those in the $4 \times$ group and in their 2 nd lactation $(705.85 \mathrm{~g})$, those in the $2 \times$ group 3 rd lactation $(544.51 \mathrm{~g})$ and those in the $2 \times$ group 2 nd lactation $(496.85 \mathrm{~g})$. Differences between the sheep in the $4 \times$ group and in their 3rd lactation and those in the same group and in their 2 nd lactation were highly significant $(P<0.01)$, but the differences between the effects of parities in the $2 \times$ group were non-significant $(P=0.62)$. This means that parity was important when the animals were milked more frequently and 3rd lactation animals responded better to the $4 \times$ treatment. All other differences for this interaction were significant as well $(P<0.05)$. Effects of parity on protein percent in milk was large enough to be significant $(P=0.02)$ and 2 nd lactation sheep had a higher percentage of protein in their milk. Differences between different parity animals were non-significant for all the other traits and the $P$-values ranged from 0.13 to 0.73 . Pala \& Savaş (2005) investigated effects of persistency and lactation on milk yield in Saanen goats and concluded that there was a sharp increase (up to $26.8 \%$ ) from first lactation to second and a relatively lower increase (20.0 to $22.2 \%$ ) from second lactation to third lactation.

Effects of parity by milking group on SCS were non-significant both for the $2 \times$ and the $4 \times$ groups (Table 4). This indicates that differences between the milking frequency groups were due to chance regardless of the parity. This is the same case as the breed by group interaction. This indicates that increasing milking frequency does not increase SCS even within parity or within breed groups, and any increase is small enough to be attributable to chance.

Effects of test day as a main effect was significant $(P<0.001)$, indicating that milk yield changed among test days. Group by test day interaction was significant $(P=0.02)$ also, indicating differences between the $2 \times$ and $4 \times$ groups were large in different test days. This can be seen in Figure 1, illustrating the increase in the $4 \times$ group during the $4 \times$ treatment and the decrease afterwards. The $2 \times$ line shows a clear decline due to the expected lactation curve. The treatment was started when the lambs were weaned, which was around 3 months after the lactation started. Koyuncu \& Pala (2008) and Dahl et al. (2004) increased milking frequency in early lactation. In contrast, in this study, the $4 \times$ period corresponds to mid to end lactation. This time frame change seems to have a positive effect, because increase in milk yield was high with 68 per cent $(352 \mathrm{~g})$, probably due to decreasing the amount of apoptosis (Stelwagen 2001) during the decline phase of the lactation by increasing the frequency of milking. Koyuncu \& Pala (2008) reported a $12 \%$ (222 g) increase in Saanen goats. Differences between the groups (Figure 1) were significant in the first test day $(P=0.02)$, second test day $(P<0.001)$, third test day $(P<0.001)$ and the fourth test day $(P=0.036)$, but were non significant in the fifth test day $(P=0.093)$. This indicates that effects of the short period frequent milking persisted until the end of lactation. Effects of testday were significant for percent fat $(P<0.01)$, percent protein $(P<0.01)$, percent non-fat solids $(P<0.01)$, percent lactose $(P<0.01)$, milk fat yield $(P<0.01)$, fat corrected milk yield $(P<0.01)$ and for SCS $(P=0.01)$. This indicates that all traits changed during the study significantly. Group by testday interaction effects were significant for percent fat $(P<0.05)$, percent nonfat solids $(P<0.05)$ and percent lactose $(P<0.01)$, while non-significant for percent protein $(P>0.05)$, milk fat yield $(P>0.05)$ and for fat corrected milk yield $(P>0.05)$. This indicates that 
differences between the $2 \times$ and $4 \times$ groups did not change for percent protein, milk fat yield and for fat corrected milk yield, but changed for percent fat, percent non-fat solids and percent lactose, in addition to milk yield.

None of the two way interactions were large enough to be significant for SCS. The $P$-values were 0.65 for breed by group, 0.06 for breed by parity, 0.81 for group by parity, 0.82 for breed by test day, 0.40 for group by test day, and 0.90 for parity by test day interactions.

In conlusion, parity differences were significant in the treatment group for milk yield and the 3rd lactation animals responded better to the $4 \times$ treatment, but the 3rd lactation animals were non-significantly different than the 2 nd lactation ones in the $2 \times$ group. This indicates that older animals are more suitable to increased milking frequency programs. Tahirova breed, which has a higher percentage of East Friesian had a lower daily milk yield compared to the Sonmez breed, which has a lower percentage of East Friesian. Results of this study suggests that increasing milking frequency for a short time (21 days) increases milk yield throughout lactation, this increase is more subtle in younger animals and sheep with too high East Friesian breeding may have lower milk yield than those with lower East Friesian breeding. In addition, Sonmez breed responded better to the $4 \times$ treatment for some traits. Increasing milking frequency did not increase SCS significantly, even when two way interactions were considered.

\section{Acknowledgements}

Partial results were orally presented at the XVII Fe. Me. S. P. Rum. International Congress, in Perugia/ltaly.

\section{References}

Akaike H (1974) A New Look at the Statistical Model Identification, IEEE Transactions on Automatic Control, AC 19, 716-723

Akçapınar H, Özbeyaz C, Ünal N, Avci M (2000) The Possibilities of Developing Dam and Sire Lines Using Akkaraman, Sakız and Kıvırcık Sheep Breeds for Lamb Production. Turkish J Vet Anim Sci 24, 71-79 [in Turkish]

Bar-Peled U, Maltz E, Bruckental I, Folman Y, Kali Y, Gacitua H, Lehrer AR, Knight CH, Robinzon B, Voet H, Tagari $H$ (1995) Relationship between frequent milking or suckling in early lactation and milk production of high producing dairy cows. J Dairy Sci 78, 2726-2736

Cimen M, Karaalp M (2009) Effect of restricted suckling time on milk components and sucking behavior of lambs. Arch Tierz 52, 299-308

Capuco AV, Ellis SE, Hale SA, Long E, Erdman RA, Zhao X, Paape MJ (2003) Lactation persistency: Insights from mammary cell proliferation studies. J Anim Sci 81, 18-31

Dahl GE, Wallace RL, Shanks RD, Lueking D (2004) Hot Topic: Effects of Frequent Milking in Early Lactation on Milk Yield and Udder Health. J Dairy Sci 87, 882-885

Demiroren E (2002) Efficiency of Lamb Production in sheep which raising different aim. Ege Üniv Ziraat Fak Derg 39, 71-77 [in Turkish]

Gursoy O, Pollott GE, Kirk K (2001) Milk production and growth performance of a Turkish Awassi flock when outcrossed with Israeli Improved Awassi rams. Livest Prod Sci 71, 31-36

Knight CH (1992) Milk yield responses to sequential treatments with recombinant bovine somatotropin and frequent milking in lactating goats. J Dairy Res 59, 115-122 
Koyuncu E, Pala A (2008). Effects of short period frequent milking on milk yield and udder health in Turkish Saanen goats. Anim Sci J 79, 111-115

Lacy-Hulbert SJ, Woolford MW, Nicholas GD, Prosser CG, Stelwagen K (1999) Effect of milking frequency and pasture intake on milk yield and composition of late lactation cows. J Dairy Sci 82, 1232-1239

Miller RH, Paape MJ, Acton JC (1986) Comparison of milk somatic cell counts by Coulter and Fossomatic Counters. J Dairy Sci 69, 1942-1946

McKusick BC, Thomas DL, Berger YM, Marnet PG (2002) Effect of milking interval on alveolar versus cisternal milk accumulation and milk production and composition in dairy ewes. J Dairy Sci 85, 2197-2206

Nudda A, Bencini R, Mijatovic S, Pulina G (2002) The yield and composition of milk in Sarda, Awassi, and Merino Sheep milked unilaterally at different frequencies. J Dairy Sci 85, 2879-2884

Olechnowicz J, Sobek Z, Jaskowski JM, Antosik P, Bukowska D (2010) Connection of somatic cell count and milk yield as well as composition in dairy ewes. Arch Tierz 53, 95-100

Pala A, Koyuncu E (2007) Effects of short period frequent milking on persistency of milk yield and SCS in Turkish Saanen goats. Anim Sci J 78, 400-406

Pala A, Savaş T (2005) Persistency Within and Between Lactations in Morning, Evening and Daily Test Day Milk in Dairy Goats (short communication). Arch Tierz 48, 396-403

Purroy UA (1986) Machine Milking of Sheep. Bull Int Dairy Fed 202, 28-41

Salama AAK, Such X, Caja G, Rovai M, Casals R, Albanell E, Marín MP, Martí A (2003) Effects of Once Versus Twice Daily Milking Throughout Lactation on Milk Yield and Milk Composition in Dairy Goats. J Dairy Sci 86, 1673-1680

Schwarz G (1978) Estimating the Dimension of a Model. Ann Stat 6, 461-464

SAS (1999) SAS OnlineDoc, Version 8, SAS Institute Inc., Cary, NC, USA

Stelwagen, K (2001) Effect of milking frequency on mammary functioning and shape of the lactation curve. J Dairy Sci 84 (E. Suppl.), E204-E211

Thomas DL, Berger YM, McKusick BC (2000) East Friesian germplasm: Effects on milk production, lamb growth, and lamb survival. J Anim Sci 77, 1-6

Received 3 January 2011, accepted 10 March 2011.

Corresponding author:

Akin Pala

email:dr.akin.pala@gmail.com or akin@comu.edu.tr

Department of Animal Science, Canakkale Onsekiz Mart University, Canakkale, Turkey 